\title{
Características morfogênicas de milheto sob lotação rotacionada com diferentes períodos de descanso ${ }^{1}$
}

\section{Carlos Eduardo da Silva Pedroso ${ }^{2}$, Pedro Lima Monks ${ }^{3}$, Otoniel Geter Lauz Ferreira ${ }^{4}$, Lasier Silveira Lima ${ }^{5}$, Otavio Matos Tavares ${ }^{5}$}

\author{
1 Pesquisa financiada pela CAPES e pelo Programa de Pós-Graduação em Zootecnia/UFPEL. \\ 2 Doutorando em Zootecnia, PPGZ, Faculdade de Agronomia, UFPEL. \\ ${ }^{3}$ PPGZ, Faculdade de Agronomia, UFPEL. \\ 4 PPGZ, Faculdade de Agronomia, UFPEL. Bolsista recém-doutor. \\ ${ }^{5}$ Curso de graduação em Agronomia, Faculdade de Agronomia, UFPEL.
}

RESUMO - O experimento foi realizado para avaliar as características morfogênicas de milheto (Pennisetum glaucum (L.) R.Br.) sob lotação rotacionada com três períodos de descanso, correspondentes aos tempo necessário para expansão de 1,5 a 2 folhas; de 2,5 a 3 folhas; e de 3,5 a 4 folhas. As características morfogênicas avaliadas em quatro repetições de área (piquetes) foram alongamento de lâminas foliares, senescência de lâminas foliares, alongamento de colmos, aparecimento de folhas, filocrono e duração de vida das folhas. As taxas de alongamento foram de 6,4; 5,8 e 5,3 cm/dia; as taxas de senescência de lâminas foliares, de 0,71; 0,82 e 1,19 cm/dia; as taxas de alongamento de colmo 0,73; 1,42 e 2,2 cm/dia; as taxas de aparecimento de folhas de 0,158; 0,119 e 0,118; e o filocrono, de 93; 118 e 128 graus-dia para os períodos de descanso de 1,5 a 2; de 2,5 a 3; e de 3,5 a 4 folhas, respectivamente. A duração de vida das folhas não foi afetada pelos períodos de descanso, entretanto, os valores médios foram muito superiores aos obtidos em estudos anteriores, portanto, não é um parâmetro eficaz para determinação do período de descanso. As taxas acumuladas das variáveis morfogênicas em estudo para o período de descanso de 1,5 a 2 folhas, somadas ao longo do ciclo de crescimento da cultura, determinam maior investimento da planta em lâminas verdes, o que resulta em melhores respostas morfogênicas do aspecto forrageiro.

Palavras-chave: folha expandida, frequência de desfolha, morfogênese, Pennisetum glaucum, rebrote

\section{Morphogenetic characteristics of pearl millet under rotational grazing with different rest periods}

\begin{abstract}
A field experiment was carried out to evaluate the morphogenetic characteristics of pearl millet (Pennisetum glaucum (L.) R.Br.), under rotational grazing with the following rest periods between grazings (RP), corresponding to the time required for expansion from: RP 1.5 to 2 leaves, RP 2.5 to 3 leaves and 3.5 to 4 leaves. Morphogenic characteristics were evaluated in four replications of the area (paddocks) and consisted of leaf blade growth, leaf senescence, stem growth, leaf appearance, phillochron and leaf life-span. The leaf blade growth rate was 6.4 , 5.8 and $5.3 \mathrm{~cm} / \mathrm{day}$, the senescence rate was $0.71,0.82$ and $1.19 \mathrm{~cm} /$ day, the stem growth rate was $0.73,1.42$ and $2.2 \mathrm{~cm} /$ day, the leaf appearance rate was $0.158,0.119$ and 0.118 , the phillochron was 93,118 and 128 degrees day for the rest periods of 1.5 to $2,2.5$ to 3 and 3.5 to 4 leaves, respectively. The leaf life span was not affected by the rest periods but the meanvalues were much higher than those obtained in previous studies, thus it is not an efficacious parameter to determine rest periods. The accumulated rates of the morphogenic variables for the 1.5 to 2 leaf rest period during the crop cycle determined a higher plant investment in leaves and, consequently, the best morphogenic responses for the forage aspect.
\end{abstract}

Key Words: defoliation frequency, expanded leaf, morphogenesis, Pennisetum glaucum, regrowth

\section{Introdução}

O milheto (Pennisetum glaucum (L.) R.Br.) éa forrageira cultivada de verão mais utilizada no Rio Grande do Sul. Os diversos estudos sob lotação contínua - tanto com ovinos quanto com bovinos - relatam que esta forrageira é bem aceita pelos animais, tolera o pisoteio e apresenta elevada produção de forragem (Moojen et al., 1999). Todavia, estudos com lotação rotacionada (Pedreira, 2002), são praticamente inexistentes, embora, para outras espécies forrageiras, trabalhos comparativos entre esses sistemas comprovem vantagem do sistema rotativo quanto à 
produção de forragem (Cauduro et al., 2007). Neste contexto, torna-se evidente a necessidade de novas pesquisas com o intuito de investigar esta alternativa de manejo para o milheto. Como ponto de partida, deve-se determinar o adequado período entre desfolhas, ou seja, o momento de máximo acúmulo de folhas vivas. Martins et al. (2005), utilizando bovinos sob pastejo contínuo em pastagem de milheto, verificaram número máximo de 5,5 folhas vivas por perfilho e que, naquele instante, 3 folhas estavam completamente expandidas. Esses resultados sugerem que, se o objetivo for trabalhar com lotação rotacionada, provavelmente o período de descanso entre desfolhas seja o necessário para que 3 novas folhas fiquem completamente expandidas, assim, apenas folhas vivas seriam colhidas. Contudo, em razão do acentuado alongamento dos entrenós das espécies anuais de estação quente, a redução desse período pode resultar em maior controle do alongamento dos entrenós e manutenção de maior qualidade da pastagem, enquanto maior período de tempo entre pastejos, além de resultar em acentuado alongamento dos entrenós, pode aumentar a senescência das lâminas foliares, comprometendo as características qualitativas da forragem. Desse modo, para determinação precisa e detalhada do adequado período entre desfolhas, torna-se fundamental conhecer o comportamento de características morfogênicas como taxa de alongamento do colmo e taxas de alongamento e senescência de lâminas foliares. Nesse sentido, realizou-se este estudo com os objetivos de estudar a pastagem de milheto sob lotação rotacionada com três períodos de descanso e verificar seu efeito nas características morfogênicas da planta.

\section{Material e Métodos}

O experimento teve duração de 143 dias (15/11/2006 a 6/4/2007) e foi realizado na propriedade Rincão do

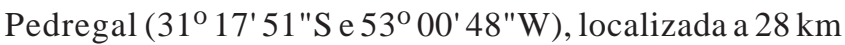
da cidade de Piratini ( 3 o distrito), na região fisiográfica da Serra do Sudeste, Rio Grande do Sul. O solo é classificado como Argissolo Bruno-acinzentado Ta Alumínico abruptico (Cunha et al., 1998) e foi submetido a preparo convencional, que consistiu inicialmente de uma subsolagem para rompimento de camadas compactadas a aproximadamente $20 \mathrm{~cm}$ de profundidade. Após a subsolagem, foram realizadas aração e duas gradagens. $\mathrm{O}$ solo foi corrigido em 30/10/2006 com aplicação de 2,5 t/ha de calcário dolomítico e adubado com $400 \mathrm{~kg} / \mathrm{ha}$ da fórmula 5-20-20 (14/11/2006). A semeadura do milheto (Pennisetum glaucum (L.) R.Br.) cv. BN2 foi feita em 15/11/2006 a lanço (manualmente) em densidade de
$35 \mathrm{~kg} / \mathrm{ha}$ (valor comercial das sementes $=100 \%$ ). A área experimental de $8.100 \mathrm{~m}^{2}$ foi subdividida em 12 piquetes de $675 \mathrm{~m}^{2}$.

Após o estabelecimento da pastagem, foi feito pastejo de uniformização em 31/12/2006, reduzindo a altura média de $60 \mathrm{~cm}$ para $30 \mathrm{~cm}$ acima do solo em todos os piquetes. Foi realizada aplicação de $65 \mathrm{~kg} / \mathrm{ha}$ de nitrogênio (na forma de ureia) em cobertura em 2/1/2007 após o pastejo de uniformização. A mesma quantidade de nitrogênio foi aplicada aproximadamente 30 dias após a primeira, no póspastejo. Foram utilizadas dez novilhas de corte por piquete com idade entre 2 e 3 anos (lotação de 2.764,41 kg) para o processo de desfolha, que durou de 1 a 2 dias. Os períodos de descanso foram determinados com base no trabalho de Martins et al. (2005), que verificaram para o milheto, conduzido sob lotação contínua, número máximo de 5,5 folhas vivas por perfilho e aproximadamente três folhas expandidas. Esses resultados sugerem que, se a intenção for trabalhar com lotação rotacionada, o período de descanso deve corresponder ao tempo necessário para a completa expansão de três novas folhas, assim, apenas folhas vivas seriam colhidas. Desse modo, avaliaram-se três períodos de descanso, correspondentes à completa expansão de 1,5 a 2 folhas; 2,5 a 3 folhas; e de 3,5 a 4 novas folhas. Em trabalhos com desfolha do milheto, têm-se recomendado rebaixamento máximo da pastagem próximo a $20 \mathrm{~cm}$ de altura (Saibro et al., 1976; Monks et al., 2005). O primeiro rebaixamento ocorreu após o período de descanso de 1,5 a 2,0 folhas. A partir daí, por meio de estimativas visuais, buscou-se manter o mesmo resíduo pós-pastejo de lâminas verdes nos três períodos de descanso estudados, tendo em vista o efeito do resíduo de lâminas verdes no rebrote da pastagem (Blaser, 1990; Carámbula, 2004). Posteriormente ao rebaixamento da pastagem, confirmou-se a semelhança do resíduo de lâminas verdes pós-pastejo (743kg/ha de MS), pela retirada de quatro amostras da pastagem por unidade experimental, cortadas rente ao solo, dentro de um quadrado de $0,25 \mathrm{~m}^{2}$. Entretanto, para manutenção da mesma massa de lâminas verdes no resíduo pós-pastejo, a altura do resíduo variou entre os três níveis do fator estudado e foi de 25 , 28 e $39 \mathrm{~cm}$ para os períodos de descanso de 1,5 a 2 ; 2,5 a 3; e 3,5 a 4 folhas, respectivamente. O delineamento experimental foi completamente ao acaso, com quatro repetições (piquetes).

Para determinação das variáveis morfogênicas, utilizou-se a técnica de "perfilhos marcados", cuja metodologia é detalhada por Carrère et al. (1997). Em cada piquete, foram marcados com fio colorido dez perfilhos representativos da pastagem e, a cada avaliação, foi medido, com régua graduada, o comprimento da fração verde das 
lâminas foliares completamente expandidas (aparecimento da lígula) ou em expansão, inclusive as senescentes. O comprimento das lâminas completamente expandidas foi medido a partir das respectivas lígulas, enquanto, o das lâminas em expansão foi medido a partir da penúltima lígula visível (Davies, 1993; Carrère et al., 1997). A senescência foi obtida pela diferença do comprimento total da lâmina e comprimento da fração verde. Foram realizadas também medidas de altura da última lígula a partir do nível do solo, para obtenção da taxa de alongamento do colmo. As avaliações foram realizadas a cada três e quatro dias (duas vezes por semana), durante os períodos de descanso do pastejo. Depois de cada processo de desfolha, foram marcados novos perfilhos visando manter a representatividade da população. Por meio dessas medições, as características morfogênicas avaliadas foram: alongamento da lâmina foliar, alongamento do colmo, senescência da lâmina foliar, aparecimento da folha, filocrono (1/taxa de surgimento das folhas), tempo de duração do alongamento da folha (número de folhas em alongamento $\times$ filocrono) e duração de vida da folha (número de folhas vivas $\times$ filocrono). $\mathrm{O}$ cálculo da soma térmica diária acumulada foi realizado por meio da equação: $\left[\left(\mathrm{t}^{\mathrm{o}} \mathrm{Mx}+\mathrm{t}^{\mathrm{o}} \mathrm{Mn}\right) / 2\right]-10$, em que $\mathrm{t}^{\mathrm{o}} \mathrm{Mx}=$ temperatura máxima, $\mathrm{t}^{\mathrm{0}} \mathrm{Mn}=$ temperatura mínima e $10^{\circ} \mathrm{C}=$ a temperatura de base (tb) do milheto (Gonçalves \& Quadros, 2003). Para obtenção do acúmulo térmico, considerou-se tb $=$ zero. Os dados meteorológicos observados no período experimental foram coletados no local do experimento utilizando-se pluviômetro e termômetro de máximas e mínimas. A precipitação pluviométrica total de 670,7 mm e as temperaturas máxima e mínima foram de 25,5 e $20,2^{\circ} \mathrm{C}$, respectivamente. Os dados foram submetidos à análise de variância e comparados pelo teste DMS Fischer $(\mathrm{P}<0,05)$, realizando-se também análise de regressão polinomial para a descrição das variáveis no tempo, também com nível de significância de 5\%.

\section{Resultados e Discussão}

O menor período de descanso entre pastejos (necessário para expansão de 1,5 a 2 novas folhas) foi em média de 12,1 dias, o intermediário (2,5 a 3 folhas) de 18,6 dias e o maior (3,5 a 4 folhas) de 22 dias. Os maiores períodos de descanso determinaram menor número de pastejos. Além do pastejo de uniformização, comum para todos os períodos de descanso, o período de descanso de 3,5 a 4 folhas possibilitou quatro pastejos; o de 2,5 a 3 folhas, cinco pastejos; e o de 1,5 a 2 folhas, sete pastejos, durante o período experimental (Tabela 1 ).

O alongamento de lâminas foliares aumentou com o período de descanso e foi de $78 \mathrm{~cm}, 108 \mathrm{~cm}$ e $116 \mathrm{~cm}$ de lâminas crescidas/perfilho para os períodos de descanso de 1,5 a 2; 2,5 a 3 e 3,5 a 4 folhas, respectivamente. Entretanto, a taxa de alongamento de folhas foi alta, tanto para o menor período de descanso (6,4 cm de lâminas/perfilho) como para o intermediário (5,8 cm de lâminas/perfilho), que não diferiu do maior período de descanso (5,3 cm de lâminas/ perfilho). Esses valores são superiores aos encontrados por Gonçalves \& Quadros (2003) e Martins et al.(2005) em trabalhos com milheto sob lotação contínua com bovinos (oferta de 12\% PV) na Depressão Central do Rio Grande do Sul. Esses autores que utilizaram adubação semelhante e encontraram alongamento de lâminas entre 1,06 e 3,3 cm/ dia. No entanto, Cândido et al. (2005a), com Panicum maximum cv. Mombaça, forrageira perene tropical sob lotação rotacionada, verificaram valores bastante semelhantes, ou seja, de 5,4 a 7,6 cm de lâminas/perfilho. Ao longo do período experimental, as taxas de alongamento de lâminas $\left(\mathrm{cm} /{ }^{\circ} \mathrm{C}\right)$ foram mais bem descritas por meio de equações quadráticas (1,5 a 2 folhas e de 3,5 a 4 folhas), embora, para o período de descanso de 2,5 a 3 folhas, esse modelo não tenha sido significativo (Figura 1).

Esse comportamento pode ser explicado parcialmente pela data da última adubação em cobertura, que ocorreu aproximadamente aos 80 dias após a semeadura. Assim, nos períodos de descanso posteriores às adubações, foram verificados acréscimos dessas taxas, seguidos de decréscimo progressivo nos períodos de descanso posteriores. O maior dreno fisiológico da planta anual para formação de raízes, colmos e órgãos reprodutivos com o avanço do ciclo de crescimento também pode sustentar essa hipótese, uma vez que o milheto é uma planta bastante precoce na iniciação da panícula e do alongamento dos entrenós. Os valores mais elevados de taxa de alongamento de lâminas foliares foram 0,$635 ; 0,748$ e $0,567 \mathrm{~cm} /{ }^{\circ} \mathrm{C}$ nos dias 94, 101 e 90 após a semeadura para os períodos de descanso de 1,5 a 2,0; 2,5 a 3; e 3,5 a 4 folhas, respectivamente.

Tabela 1 - Duração, soma térmica, acúmulo térmico, número de períodos de descanso e desvio-padrão da média dos períodos de descanso

\begin{tabular}{llccc}
\hline Período de descanso & Duração (dias) & Soma térmica $\left({ }^{\circ} \mathrm{C}\right)$ & Acúmulo térmico $\left({ }^{\circ} \mathrm{C}\right)$ & $\mathrm{N}^{\mathrm{0}}$ de $\mathrm{PDs}$ \\
\hline 1,5 a 2 folhas & $12,14( \pm 1,57)$ & $160,85( \pm 19,35)$ & $282,27( \pm 32,4)$ \\
2,5 a 3 folhas & $18,60( \pm 2,20)$ & $246,14( \pm 21,23)$ & $432,14( \pm 44,65)$ & 7 \\
3,5 a 4 folhas & $22,00( \pm 2,16)$ & $292,68( \pm 38,32)$ & $513,05( \pm 45,47)$ \\
\hline
\end{tabular}



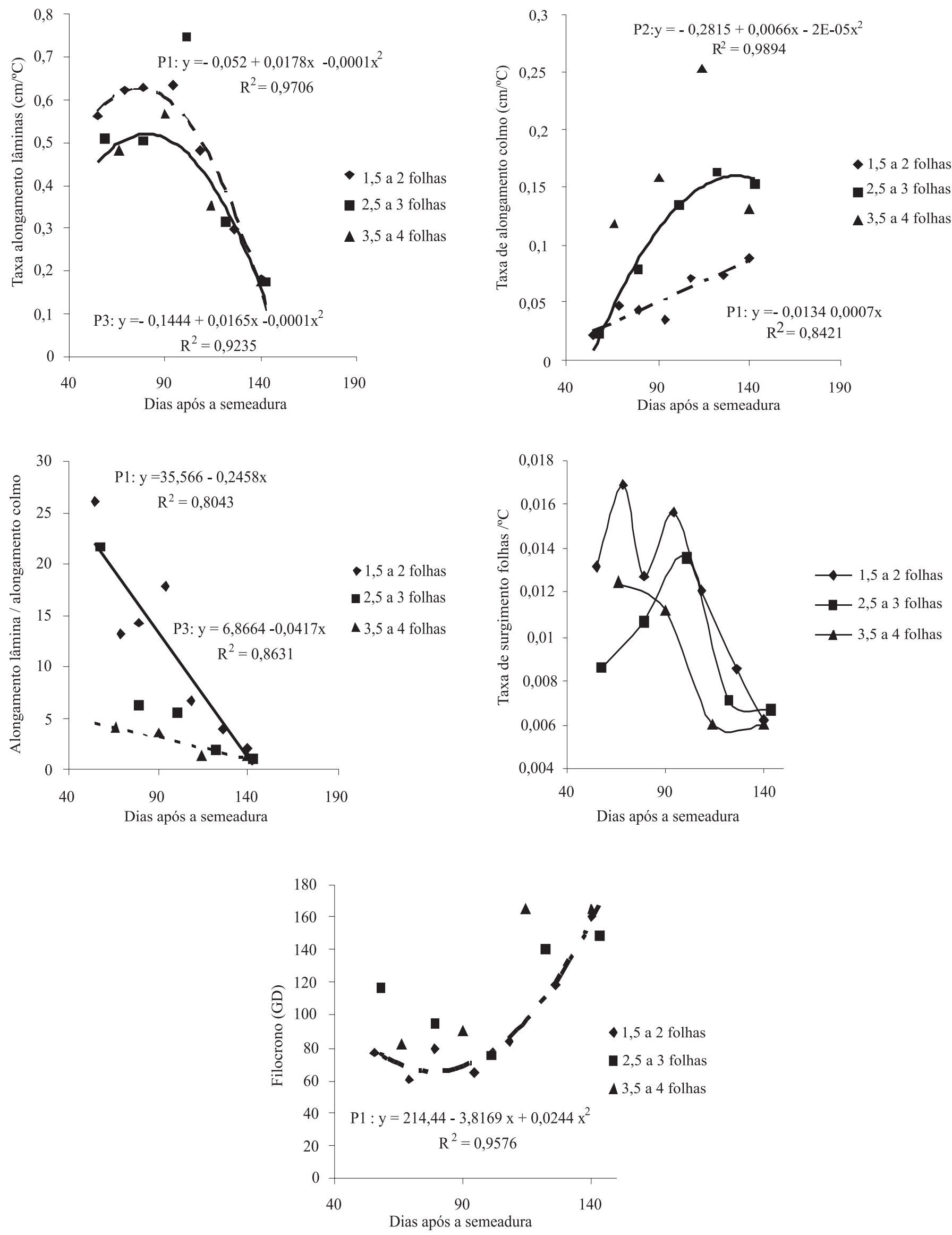

Figura 1 - Relações entre as características morfogênicas e os dias após semeadura em cada período de descanso. 
Por outro lado, os menores valores de taxa de alongamento de lâminas foliares foram verificados na última avaliação e foram de 0,$181 ; 0,175$; e $0,174 \mathrm{~cm} /{ }^{\circ} \mathrm{C}$, respectivamente. No decorrer das avaliações, as maiores diferenças no alongamento de lâminas ocorreram entre o maior e o menor período de descanso, principalmente até o 120 으 dia após a semeadura. Como consequência, o alongamento acumulado, do estabelecimento ao final do ciclo da planta, foi mais elevado, tanto para o menor período de descanso (573,16 cm/perfilho) quanto para o intermediário (517 cm/perfilho), que não diferiu do maior período de descanso avaliado (469,3 cm/perfilho - Tabela 2). Os maiores alongamentos de lâminas ao longo das avaliações provavelmente estão associados aos rebaixamentos menos significativos da altura do dossel: no período de descanso de 1,5 a 2 folhas, rebaixou-se de 54 para $25 \mathrm{~cm}$; no de 2,5 a 3 folhas, rebaixou-se de 82 para $28 \mathrm{~cm}$; e no maior período de descanso (3,5 a 4 folhas), rebaixou-se de 107 para $39 \mathrm{~cm}$. Apoiando essa teoria, Maraschin (1996) recomendou manejar a pastagem de milheto sem proceder a rebaixamentos significativos na altura da pastagem, evitando o comprometimento do resíduo com a retirada de elevada proporção de material fotossinteticamente ativo. Marcelino et al. (2006), em experimento com Brachiaria brizantha, cv. Marandu, também verificaram maior taxa de crescimento de lâminas quando houve rebaixamento menos intenso das plantas e acrescentaram que cortes mais frequentes promovem maior renovação de tecidos no dossel da pastagem.

Outro fator que provavelmente contribuiu para as menores taxas de alongamento de lâminas foliares no maior período de descanso foi o fato de alguns perfilhos marcados não terem o número de folhas exigidas. Nesse caso, por exemplo, três folhas passavam da fase em expansão para completamente expandidas e, na sequência, para inflorescência. Com a última folha do perfilho já expandida (bandeira), não há mais alongamento de lâminas foliares e essa situação se estendeu até que esses perfilhos, associados aos demais perfilhos marcados da unidade experimental, atingissem a média mínima exigida, ou seja, que 3,5 novas folhas se tornassem completamente expandidas.

O alongamento de colmos aumentou com o período de descanso e atingiu 6,7 cm para o período de descanso de 1,5 a 2 folhas; $19 \mathrm{~cm}$ para o de 2,5 a 3 folhas; e $36,8 \mathrm{~cm}$ para o de 3,5 a 4 folhas. As taxas de alongamento de colmos ( $\mathrm{cm} /$ dia e $\mathrm{cm} /{ }^{\circ} \mathrm{C}$ ) também foram maiores nos maiores tempos de descanso, com valores de 1,5 a 2; de 2,5 a 3 e de 3,5 a 4 folhas alongamentos de 0,73; 1,42 e 2,2 cm/dia. Esses valores são bastante elevados em comparação aos disponíveis na literatura para outras gramíneas perenes tropicais, visto que não foram encontrados registros para o milheto. Resultados semelhantes aos encontrados no menor período de descanso nos meses de outubro a dezembro $(0,71 \mathrm{~cm} /$ perfilho.dia $)$ foram relatados por Santos et al. (2004) em trabalho com P. maximum cv. Mombaça. No entanto, a maior parte dos trabalhos com gramíneas perenes tropicais de verão cita taxas de alongamento de colmos entre 0,2 e 0,4 cm/perfilho/dia (Cândido et al., 2005a; Marcelino et al., 2006), o que confirma a característica de precocidade e elevada velocidade no alongamento dos entrenós da cultura do

Tabela 2 - Alongamento de lâmina foliar, alongamento de colmos, senescência de lâmina foliar e aparecimento de folhas por período de descanso no período total de avaliações

\begin{tabular}{|c|c|c|c|c|}
\hline Período de descanso & Período & Dia & ${ }^{\circ} \mathrm{C}$ & Período total de avaliações \\
\hline \multicolumn{5}{|c|}{ Alongamento de lâmina foliar (cm) } \\
\hline 1,5 a 2 folhas & $78 \mathrm{c}$ & $6,44 a$ & $0,486 a$ & $573,1 \mathrm{a}$ \\
\hline 2,5 a 3 folhas & $108 \mathrm{~b}$ & $5,80 \mathrm{ab}$ & $0,450 \mathrm{ab}$ & $517,0 \mathrm{ab}$ \\
\hline 3,5 a 4 folhas & $116 a$ & $5,30 \mathrm{~b}$ & 0,393b & $469,3 b$ \\
\hline \multicolumn{5}{|c|}{ Alongamento de colmos (cm) } \\
\hline 1,5 a 2 folhas & $6,7 \mathrm{c}$ & $0,73 c$ & $0,054 \mathrm{c}$ & $64,97 c$ \\
\hline 2,5 a 3 folhas & $19,0 \mathrm{~b}$ & $1,42 b$ & $0,110 \mathrm{~b}$ & $126,38 b$ \\
\hline 3,5 a 4 folhas & $36,8 \mathrm{a}$ & $2,20 \mathrm{a}$ & $0,165 \mathrm{a}$ & $196,69 a$ \\
\hline \multicolumn{5}{|c|}{ Senescência de lâmina foliar (cm) } \\
\hline 1,5 a 2 folhas & $8,61 \mathrm{c}$ & $0,71 b$ & $0,053 b$ & $63,19 b$ \\
\hline 2,5 a 3 folhas & $15,25 b$ & $0,82 b$ & $0,063 b$ & $72,98 b$ \\
\hline 3,5 a 4 folhas & $26,18 \mathrm{a}$ & $1,19 a$ & $0,089 a$ & $105,90 \mathrm{a}$ \\
\hline \multicolumn{5}{|c|}{ Aparecimento de folhas } \\
\hline 1,5 a 2 folhas & $1,9 b$ & $0,158 \mathrm{a}$ & $0,011 \mathrm{a}$ & $14,1 \mathrm{a}$ \\
\hline 2,5 a 3 folhas & $2,2 b$ & $0,119 b$ & $0,009 b$ & $10,6 b$ \\
\hline 3,5 a 4 folhas & $2,6 a$ & $0,118 b$ & $0,008 b$ & $10,5 b$ \\
\hline
\end{tabular}

Valores com letras iguais na mesma coluna não diferem $(\mathrm{P}<0,05)$ pelo teste de DMS. 
milheto, trazendo implicações importantes ao manejo dos animais. Nessa situação, além de redução na qualidade da pastagem, em decorrência da menor qualidade do colmo em relação à folha, ocorre também comprometimento da estrutura da pastagem, principalmente em virtude da menor densidade de folhas.

A taxa de alongamento de colmos durante o menor período de descanso foi mais bem descrita por uma equação linear positiva com declividade muito pouco acentuada, enquanto, nos demais períodos de descanso, os alongamentos em relação ao tempo foram maiores desde o início das avaliações. O maior período de descanso diferiu do intermediário, uma vez que esta tendência foi mais acentuada, principalmente no dia 114 após a semeadura, quando atingiu seu valor máximo de $0,252 \mathrm{~cm} /{ }^{\circ} \mathrm{C}$, bastante superior ao máximo encontrado para o período de 2,5 a 3 folhas, que foi de $0,164 \mathrm{~cm} /{ }^{\circ} \mathrm{C}$ no dia 122 após a semeadura da cultura (Figura 1).

Em resposta à evolução destas taxas ao longo do período experimental, o alongamento acumulado de colmos foi mais elevado para o maior período de descanso (196,69 cm) em relação ao período de descanso intermediário $(126,38 \mathrm{~cm})$ e ao menor período de descanso estudado $(64,97 \mathrm{~cm})$. A partir desses dados, com a redução do período de descanso, foi obtido o maior controle do alongamento dos entrenós e, por consequência, a participação de material de maior qualidade no dossel. Sabe-se que a lâmina apresenta maior qualidade em relação ao colmo, logo, para avaliar a participação da lâmina, componente estrutural mais selecionado pelos ruminantes na pastagem, em cada período de descanso, utilizou-se a relação taxa de alongamento de lâmina (AL)/taxa de alongamento de colmos (AC). Observou-se queda acentuada desta relação ao longo do período experimental para os três períodos de descanso estudados e essa queda foi linear para o maior e para o menor período de descanso (Figura 1).

O intercepto do período de descanso de 1,5 a 2 folhas $(35,566)$ muito superior ao do período de descanso de 3,5 a 4 folhas $(6,8664)$ reflete as diferenças entre esses períodos de descanso ao longo das avaliações. No período de descanso de 2,5 a 3 folhas, no entanto, apesar de inicialmente ter ocorrido elevada relação alongamento lâmina/alongamento colmo, no restante das avaliações, esses valores reduziram acentuadamente, mas mantiveram-se superiores aos obtidos no maior período de descanso. Assim, o maior alongamento de lâminas em relação ao de colmos ocorreu no menor período de descanso, cuja taxa de alongamento médio de lâminas foi 12 vezes superior à de alongamento médio de colmos, em comparação ao período de descanso intermediário e ao maior período de descanso estudado, cujas taxas de alongamento de lâminas foram 7,32 e 2,59 vezes superiores às de alongamento de colmos. Cândido et al. (2005b), trabalhando com diferentes períodos entre pastejo (período de descanso para a formação de 2,5; 3,5 e 4,5 novas folhas expandidas) de $P$. maximum cv. Mombaça, verificaram para o menor período de descanso maior controle do alongamento dos entrenós e melhor qualidade da pastagem disponível.

A senescência de lâminas aumentou com o período de descanso (1,5 a 2 folhas $=8,61 \mathrm{~cm} ; 2,5$ a 3 folhas $=15,25 \mathrm{~cm}$; e 3,5 a 4 folhas $=26,18 \mathrm{~cm}$ ) de forma linear positiva em relação ao avanço da época de avaliação. Entretanto, a taxa de senescência diária foi maior no maior período de descanso $(1,19 \mathrm{~cm})$ e não diferiu dos demais períodos de descanso ( 1,5 a 2 folhas $=0,71 \mathrm{~cm} ; 2,5$ a 3 folhas $=0,82 \mathrm{~cm}$ ), o que fez com que a senescência acumulada durante todo o período de avaliações fosse mais acentuada no maior período de descanso (105,9 cm) em relação ao intermediário $(72,98 \mathrm{~cm})$ e ao menor $(63,19 \mathrm{~cm})$, que se mantiveram semelhantes. Os valores obtidos, de modo geral, não podem ser considerados elevados, pois a senescência ocorreu apenas em lâminas completamente expandidas remanescentes do pastejo. As lâminas que estavam em alongamento no início do período de descanso mantiveram-se vivas até o término do período de descanso. Essa ação do processo de senescência também pôde ser verificada por meio da relação entre a taxa de alongamento de lâmina e a taxa de senescência de lâmina, pois o alongamento de lâmina foi 12,8; 9,1 e 5,2 vezes superior à senescência de lâminas nos períodos de descanso de 1,5 a 2; de 2,5 a 3 e de 3,5 a 4 folhas, respectivamente. Apesar da redução na relação alongamento/senescência, o balanço foi positivo para todos os períodos de descanso. Martins et al. (2005), analisando a senescência de milheto sob lotação contínua nas alturas de 40 a $50 \mathrm{~cm}$ da pastagem, assim como Martuscello et al. (2005), Fagundes et al. (2006) e Paciullo et al. (2003) em experimento com gramíneas perenes de verão, verificaram valores muito semelhantes para taxa de senescência de folhas. No entanto, Santos et al. (2004), em avaliações com Panicum maximum cv. Mombaça com período de descanso de 48 dias, ou seja, 2,18 vezes superior ao maior período de descanso avaliado neste trabalho, verificaram valores superiores (2,07 cm/perfilho.dia).

$\mathrm{O}$ aparecimento de folhas foi mais elevado no maior período de descanso (2,6 folhas) e não diferiu entre os demais (1,5 a 2 folhas = 2,2 folhas; 2,5 a 3 folhas = 1,9 folha). Contudo, no menor período de descanso, o aparecimento diário de folhas (0,158 folha) foi maior em comparação ao 
período de descanso intermediário (0,119 folhas) e ao maior (0,118 folhas), que não diferiram entre si (Tabela 2). As menores taxas de aparecimento de folhas nos maiores períodos de descanso provavelmente estão relacionadas às maiores alturas das plantas ( 1,5 a 2 folhas $=54 \mathrm{~cm} ; 2,5$ a 3 folhas $=80$; e 3,5 a 4 folhas $=106 \mathrm{~cm}$ ). Como resultado desse aumento na estatura das plantas, o caminho para a folha surgir torna-se cada vez mais longo pelo processo natural do alongamento da bainha, pois ocorre aumento no trajeto entre seu ponto de conexão com o meristema e a extremidade do pseudocolmo (Garcez Neto et al., 2002). Esse fato, associado às menores taxas de alongamento de lâminas foliares, determinou as menores taxas de aparecimento de folhas nos maiores períodos de descanso estudados. Esses resultados são semelhantes aos verificados nessa mesma cultura sob lotação contínua (Gonçalves \& Quadros, 2003; Martins et al., 2005) para Brachiaria brizantha cvs. Xaraés (Martuscello et al., 2005) e Marandu (Marcelino et al., 2006), P. maximum cvs. Mombaça e Tanzânia (Gomide \& Gomide, 2000; Oliveira et al., 2007) e Pennisetum purpureum (Paciullo et al., 2003). Entretanto, foram superiores às verificadas para azevém-anual (Lolium multiflorum Lam.) sob lotação contínua de ovinos e bovinos (Pontes et al., 2003; Quadros \& Bandinelli, 2005).

Durante o ciclo de crescimento da cultura, inicialmente a taxa de aparecimento de folhas no período de descanso de 1,5 a 2 folhas foi bastante superior à verificada para o período de descanso intermediário, ainda que essas diferenças tenham se reduzido a partir do $100^{0}$ dia após a semeadura. No maior período de descanso, com exceção da última avaliação, manteve-se decrescente e, desde o $90^{\circ}$ o dia após a semeadura, com valores inferiores aos demais períodos de descanso (Figura 1). Com isso, para o menor período de descanso, observou-se um total de 14,1 folhas surgidas a partir do pastejo de uniformização até o término das avaliações. Essa média foi superior à encontrada para os períodos de descanso de 2,5 a 3 folhas (10,6 folhas surgidas) e de 3,5 a 4 folhas (10,5 folhas surgidas), que foram semelhantes entre si.

Os tempos estimados de duração de vida da folha foram semelhantes entre os períodos de descanso (1,5 a 2 folhas $=635^{\circ} \mathrm{C} / 47$ dias; 2,5 a 3 folhas $=751^{\circ} \mathrm{C} / 54$ dias; 3,5 a 4 folhas $=721{ }^{\circ} \mathrm{C} / 56$ dias) e variaram ao longo do tempo, com limite mínimo de $474{ }^{\circ} \mathrm{C}$ para o período de descanso intermediário, no $101^{\circ}$ após a semeadura e o limite máximo de $988{ }^{\circ} \mathrm{C}$ (69 dias) para o menor período de descanso, no final das avaliações no $140^{\circ}$ após a semeadura (Tabela 3). Gonçalves \& Quadros (2003), em estudo com milheto, verificaram valores de duração de vida das folhas bastante inferiores, de 290 a $372{ }^{\circ} \mathrm{C}$. Essas diferenças devem-se, em parte, ao fato de esses autores considerarem apenas folhas não pastejadas; enquanto neste trabalho, foram incluídas no cálculo. Por outro lado, Martins et al. (2005), na mesma espécie forrageira, verificaram amplitude de valores semelhante, com valores médios entre 939 a $472{ }^{\circ} \mathrm{C}$ nos meses de janeiro e fevereiro para as alturas de 30 a 40 e de 20 a $30 \mathrm{~cm}$, respectivamente.

A duração de vida da folha do azevém-anual também apresenta elevadas variações, entre 1.237 e $686^{\circ} \mathrm{C}$ em lotação rotacionada de cordeiros no primeiro e segundo ciclos de pastejo (Cauduro et al., 2006) e em pastos de azevém $\left(693{ }^{\circ} \mathrm{C}\right)$ (Pontes et al., 2003). Esses resultados evidenciam que a duração de vida da folha, embora recomendada para pastagens hibernais (Cauduro et al., 2006), não é adequada para determinar o tempo de descanso em pastagem de milheto em sistema de lotação rotacionada, uma vez que o maior período de descanso estudado (3,5 a 4 folhas: 22 dias) correspondeu a apenas $40 \%$ da duração de vida das folhas (56 dias). No entanto, aos 22 dias de descanso, foram verificadas características morfogênicas indesejáveis sob o ponto de vista forrageiro, como maiores taxas de senescência foliar, de alongamento de colmos e menores taxas de alongamento de lâminas, em comparação às observadas nos menores períodos de descanso estudados. Um parâmetro que poderia ser utilizado para determinar o período de descanso seria o tempo de duração do alongamento das folhas, que foi semelhante entre os períodos de descanso ( 1,5 a 2 folhas $=244^{\circ} \mathrm{C} / 19$ dias; 2,5 a 3 folhas $=305^{\circ} \mathrm{C} / 23$ dias; e 3,5 a 4 folhas $=255^{\circ} \mathrm{C} / 18$ dias). Por meio das características morfogênicas, observou-se que, quando o período de descanso (de 1,5 a 2 folhas $=12$ dias; de 2,5 a 3 folhas $=18,6$ dias e de 3,5 a 4 folhas $=22$ dias)

Tabela 3 - Duração de vida da folha, duração do alongamento da folha e filocrono em graus dia e dias para os diferentes períodos de descanso

\begin{tabular}{|c|c|c|c|c|c|c|}
\hline \multirow[t]{2}{*}{ Período de descanso } & \multicolumn{2}{|c|}{ Duração de vida da folha } & \multicolumn{2}{|c|}{ Duração do alongamento da folha } & \multicolumn{2}{|c|}{ Filocrono } \\
\hline & Graus-dia & Dias & Graus-dia & Dias & Graus-dia & Dias \\
\hline 1,5 a 2 folhas & 635 & 47 & 244 & 19 & $93 a$ & $6,38 a$ \\
\hline 2,5 a 3 folhas & 751 & 54 & 305 & 23 & $118 \mathrm{a}$ & $8,45 b$ \\
\hline 3,5 a 4 folhas & 721 & 56 & 255 & 18 & $128 b$ & $8,46 b$ \\
\hline
\end{tabular}

Valores com letras iguais na mesma coluna não diferem $(\mathrm{P}<0,05)$ pelo teste de DMS. 
ultrapassou a duração do alongamento da folha, como verificado no maior período de descanso (PD 20\% superior à duração do alongamento da folha), ocorreram maior senescência, alongamento de colmos e menor investimento em lâminas foliares em comparação a quando a duração do alongamento da folha não foi ultrapassado pelo período de descanso (1,5 a 2 folhas e 2,5 a 3 folhas).

O menor filocrono foi verificado no menor período de descanso (de 1,5 a 2 folhas $=93$ graus-dia) e não diferiu entre os demais períodos de descanso (2,5 a 3 folhas $=118$ graus-dia; e 3,5 a 4 folhas $=128$ graus-dia). Valores superiores foram observados por Pontes et al. (2003) e Quadros \& Bandinelli (2005) em experimentos com azevém-anual. Por outro lado, em trabalhos com espécies estivais, tanto anuais como perenes, os resultados foram semelhantes aos deste estudo (Martins et al., 2005; Martuscello et al., 2005).

No decorrer do período experimental, a regressão polinomial de segundo grau foi a que melhor descreveu a variável filocrono no período de descanso de 1,5 a 2 folhas, no qual os valores foram praticamente sempre inferiores e oscilaram de 60 a 159 graus-dia, de modo que, até o 108ํ dia após a semeadura, os registros foram próximos a 80 grausdia (Figura 5). A manutenção desses menores valores evidencia melhor adaptação das plantas ao manejo, pois o menor filocrono significou menos graus-dia necessários para o surgimento de duas folhas consecutivas. Desse modo, a energia disponível para a planta foi mais bem aproveitada para o aparecimento e alongamento de folha, fração de maior interesse da pastagem. Nos períodos de descanso de 2,5 a 3 e de 3,5 a 4 folhas, os maiores filocronos registrados refletem, provavelmente, necessidade de maiores investimentos (graus-dia) em estruturas de adaptação da planta aos processos intermitentes de desfolha adotados (renovações de raízes, adaptação de folhas a maior intensidade luminosa, entre outros fatores de estresse) em detrimento ao aparecimento e alongamento de novas folhas.

\section{Conclusões}

As características morfogênicas são afetadas pelos períodos de descanso e, de acordo com as variáveis morfogênicas estudadas, o período de descanso deve ser o necessário para formação de 1,5 a 2 folhas expandidas para a cultura do milheto. A duração de vida da folha não é parâmetro adequado para definir o intervalo de descanso. Períodos de descanso superiores ao necessário para formação de 3,5 folhas expandidas tornam todas as características morfogênicas estudadas indesejáveis do ponto de vista forrageiro.

\section{Literatura Citada}

BLASER, R.E. Manejo do complexo pastagem-animal para avaliação de plantas e desenvolvimento de sistemas de produção de forragem. In: PEIXOTO, A.M.; MOURA, J.C.; FARIA, V.P. (Eds.). Pastagens. Piracicaba: Fundação de Estudos Agrários Luiz de Queiroz, 1990. p.279-335.

CÂNDIDO, M.J.D.; GOMIDE, C.A.M.; ALEXANDRINO, E. et al. Morfofisiologia do dossel de Panicum maximum cv. Mombaça sob lotação intermitente com três períodos de descanso. Revista Brasileira de Zootecnia, v.34, n.2, p.406-415, 2005a.

CÂNDIDO, M.J.D.; ALEXANDRINO, E.; GOMIDE, C.A.M. et al. Período de descanso, valor nutritivo e desempenho animal em pastagem de Panicum maximum cv. Mombaça sob lotação intermitente. Revista Brasileira de Zootecnia, v.34, n.5, p.1459-1467, 2005b.

CARÁMBULA, M. Pasturas y forrajes: manejo, persistencia y renovación de pasturas. Montevideo: Editorial Hemisferio Sur, 2004, v.3. 413p.

CARRÈRE, P.; LOUAULT, F.; SOUSSANA, J.F. Tissue turnover within grass-clover mixed swards grazed by sheep. Methodology for calculating growth, senescence and intake fluxes. Journal of Applied Ecology, v.34, p.333-348, 1997.

CAUDURO, G.F.; CARVALHO, P.C.F.; BARBOSA, C.M.P. et al. Variáveis morfogênicas e estruturais de azevém anual (Lolium multiflorum Lam.) manejado sob diferentes intensidades e métodos de pastejo. Revista Brasileira de Zootecnia, v.35, n.4, p.1298-1307, 2006.

CAUDURO, G.F.; CARVALHO, P.C.F.; BARBOSA, C.M.P. et al. Fluxo de biomassa aérea em azevém anual manejado sob duas intensidades e dois métodos de pastejo. Revista Brasileira de Zootecnia, v.36, n.2, p.282-290, 2007.

CUNHA, N.G.; SILVEIRA, R.J.C.; SEVERO, C.R.S. et al. Estudos dos solos do município de Piratini. Pelotas: EMBRAPACPACT, 1998. 91p. (Documentos, 26).

DAVIES, A. Tissue turnover in the sward. In: DAVIES, A.; BAKER, R.D.; GRANT, S.A. et al. (Eds.) Sward measurement handbook. London: British Grassland Society, 1993. p.183-216.

FAGUNDES, J.L.; FONSECA, D.M.; MISTURA, C. et al. Características morfogênicas e estruturais do capim-braquiária em pastagem adubada com nitrogênio avaliadas nas quatro estações do ano. Revista Brasileira de Zootecnia, v.35, n.1, p.21-29, 2006.

GARCEZ NETO, A.F.; NASCIMENTO JR., D.; REGAZZI, A.J. et al. Respostas morfogênicas e estruturais de panicum maximum cv. Mombaça sob diferentes níveis de adubação nitrogenada e alturas de corte. Revista Brasileira de Zootecnia, v.31, n.5, p.1890-1900, 2002.

GOMIDE, C.A.M.; GOMIDE, J.A. Morfogênese de cultivares de Panicum maximum Jacq. Revista Brasileira de Zootecnia, v.29, n.2, p.341-348, 2000.

GONÇALVES, E.N.; QUADROS, F.L.F. Morfogênese de milheto (Pennisetum americanum L. Leeke) em pastejo com terneiras, recebendo ou não suplementação. Ciência Rural, v.33, n.6, p.1123-1128, 2003.

MARASCHIN, G.E. Produção de carne a pasto. In: SIMPÓSIO SOBRE MANEJO DA PASTAGEM, 13., 1997, Piracicaba. Anais... Piracicaba: Fundação de Estudos Agrários Luiz de Queiroz, 1996. p.243-274.

MARCELINO, K.R.A.; NASCIMENTO JR., D.; SILVA, S.C. et al. Características morfogênicas e estruturais e produção de forragem do capim-marandu submetido a intensidades e freqüência de desfolhação. Revista Brasileira de Zootecnia, v.35, n.6, p.2243-2252, 2006.

MARTINS, C.E.N.; QUADROS, F.L.F.; BANDINELLI, D.G. Variáveis morfogênicas de milheto (Pennisetum americanum) mantido em duas alturas de pastejo. Ciência Rural, v.35, n.1, p.174-180, 2005 
MARTUSCELLO, J.A.; FONSECA, D.M.; NASCIMENTO JR., D. et al. Características morfogênicas e estruturais do capim-xaraés submetido a adubação nitrogenada e desfolhação. Revista Brasileira de Zootecnia, v.34, n.5, p.1475-1482, 2005.

MONKS, P.L.; FERREIRA, O.G.L.; PESKE, S.T. Produção e qualidade da forragem, antes e após a colheita de sementes, de milheto submetido a diferentes sistemas de cortes. Revista Brasileira de Agrociência, v.11, n.2, p.227-230, 2005.

MOOJEN, E.L.; RESTle, J.; LUPATINI, G.C. et al. Produção animal em pastagem de milheto sob diferentes níveis de nitrogênio Pesquisa Agropecuária Brasileira, v.34, n.11, p.2145-2149, 1999.

OLIVEIRA, A.B.; PIRES, A.J.V.; MATOS NETO, U. et al. Morfogênese do capim-tanzânia submetido a adubações e intensidades de corte. Revista Brasileira de Zootecnia, v.36, n.4, p.1006-1013, 2007.

PACIULLO, D.S.C; DERESZ, F.; AROEIRA, L.J.M et al. Morfogênese e acúmulo de biomassa foliar em pastagem de capim-elefante avaliada em diferentes épocas do ano Pesquisa Agropecuária Brasileira, v.38, n.7, p.881-887, 2003.
PEDREIRA, C.G.S. Avanços metodológicos na avaliação de pastagens. In: REUNIÃO ANUAL DA SOCIEDADE BRASILEIRA DE ZOOTECNIA, 39., 2002, Recife. Palestras... Brasília: Sociedade Brasileira de Zootecnia, 2002. v.1. p.100-150.

PONTES, L.S.; NABINGER, C.; CARVALHO, P.C.F. et al. Variáveis morfogênicas e estruturais de azevém anual (Lolium multiflorum Lam.) manejado em diferentes alturas. Revista Brasileira de Zootecnia, v.32, n.4, p.814-820, 2003.

QUADROS, F.L.F.; BANDINELLI, D.G. Efeitos da adubação nitrogenada e sistemas de manejo sobre a morfogênese de Lolium multiflorum Lam. e Paspalum urvillei Steud. em ambiente de várzea. Revista Brasileira de Zootecnia, v.34, n.1, p.44-53, 2005.

SAIBRO, J.C.; MARASCHIN, G.E.; BARRETO, I.L. Avaliação do comportamento produtivo de cultivares de sorgo, milho e milheto forrageiros no Rio Grande do Sul. Anuário Técnico do Instituto de Pesquisas Zootécnicas “Francisco Osório", v.3, p.290-304, 1976.

SANTOS, P.M.; BALSALOBRE, M.A.A.; CORSI, M. Característica morfogênica e taxa de acúmulo de forragem do capim mombaça submetido a três intervalos de pastejo. Revista Brasileira de Zootecnia, v.33, n.4, p.843-851, 2004. 